\title{
Ascorbic acid in some oleiferous brassicas cultivated in Pakistan
}

\author{
BY SULTAN AHMAD TREMAZI \\ Agricultural College and Research Institute, Lyallpur, Pakistan \\ (Received 7 Fanuary 1956-Revised 28 April 1956)
}

Certain forms of oleiferous brassicas (brown-seeded sarson, Japan rapes and toria) are grown in Pakistan as oilseeds and fodder crops, and some varieties of these have been introduced recently as new crops in consequence of work done at the Agricultural Research Institute, Lyallpur. In the young stage the plants are eaten as vegetables; the non-fibrous stem known as gandal mixed with the young branches and leaves is cooked as sag by the villagers in winter. It is well known that leafy vegetables, particularly if eaten raw, form a valuable source of ascorbic acid in the diet, so the ascorbic-acid content of the oleiferous brassicas mentioned above has been investigated. The results of the work over a period of 2 years (1950-I) are now described.

\section{EXPERIMENTAL}

Two forms of Japan rape (light- and dark-green leaved), brown-seeded sarson and toria were grown in plots. Five plants were removed from each plot on each day of sampling; the plants of each variety were pooled in one sample and were divided into stems, branches, leaves and buds for analysis. The samples were thus representative of the whole plot. Analyses for ascorbic acid were carried out in duplicate on each sample and the results were averaged.

Samples of each variety were taken at two stages of development, one before, and the other immediately after, blooming, that is while the plants were quite fit for culinary purposes. Beyond the blooming stage the stems become too fibrous for use. The effects of cooking and storage were studied.

A large number of undeveloped, fully grown immature and mature seeds was collected from the pods of each crop so as to make a composite and representative sample, a portion of which was analysed for ascorbic-acid content. Seeds of the four crops were germinated and the ascorbic-acid content was determined at different stages.

Ascorbic acid was determined by the 2 :6-dichlorophenolindophenol method (Harris \& Olliver, 1942) in extracts of the plant tissues.

In preparing the extracts $5 \mathrm{~g}$ of the sample were ground with about $10 \mathrm{~g}$ fine sand and a few $\mathrm{ml} .3 \%(\mathrm{w} / \mathrm{v})$ metaphosphoric-acid solution; the mixture was immediately filtered and the residue well washed with metaphosphoric-acid solution; portions of the extract were immediately titrated with the dye solution. 


\section{RESULTS AND DISCUSSION}

\section{Ascorbic-acid content of the fresh tissues}

The ascorbic-acid content of fresh samples from the different tissues of the four varieties is given in Table $\mathrm{I}$. The results for the 2 years were in fair agreement. They showed that there was a considerable drop in ascorbic-acid content after flowering and that great differences existed in the ascorbic-acid content of the different parts of the plant, the stem containing relatively little and the leaves and buds being exceptionally rich. The leaves contain the largest amount of calcium and the buds the largest amount of phosphorus and, since those parts are rich also in ascorbic acid, it is evident that they should be retained when preparing the plants for consumption. In Pakistan it is usual to consume the stems ( $g$ andal) and discard the leaves for no apparent reason except convention.

Table I. Mean concentration of ascorbic acid in fresh tissues of oleiferous brassicas

\begin{tabular}{|c|c|c|c|c|c|c|}
\hline \multirow[b]{2}{*}{ Name of crop } & \multirow[b]{2}{*}{ Stage of sampling } & \multirow[b]{2}{*}{ Year } & \multicolumn{4}{|c|}{ Ascorbic-acid content of: } \\
\hline & & & $\begin{array}{c}\text { Stem } \\
\text { (ithg/100 g) }\end{array}$ & $\begin{array}{l}\text { Branches } \\
(\mathrm{mg} / \mathrm{roog})\end{array}$ & $\begin{array}{l}\text { Leaves } \\
(\mathrm{mg} / 100 \mathrm{~g})\end{array}$ & $\begin{array}{c}\text { Buds } \\
\text { (mg/100 g) }\end{array}$ \\
\hline Toria & $\begin{array}{l}\text { Before blooming } \\
\text { Mean }\end{array}$ & $\begin{array}{l}1949-50 \\
1950-1\end{array}$ & $\begin{array}{l}68 \cdot 3 \\
73 \cdot 8 \\
71 \cdot 0\end{array}$ & $\begin{array}{l}126.9 \\
103.2 \\
115.0\end{array}$ & $\begin{array}{l}194 \cdot 5 \\
205^{\cdot 8} \\
200 \cdot 1\end{array}$ & $\begin{array}{l}199.3 \\
250.3 \\
224 \cdot 8\end{array}$ \\
\hline & $\begin{array}{l}\text { After blooming } \\
\text { Mean }\end{array}$ & $\begin{array}{l}1949^{-}-50 \\
195^{\circ-1}\end{array}$ & $\begin{array}{l}64 \cdot 6 \\
66 \cdot 0 \\
65 \cdot 3\end{array}$ & $\begin{array}{l}83 \cdot 8 \\
95 \cdot 7 \\
89 \cdot 7\end{array}$ & $\begin{array}{l}134 \cdot 4 \\
178 \cdot 5 \\
156 \cdot 4\end{array}$ & $\begin{array}{l}180 \cdot 7 \\
214 \cdot 7 \\
202 \cdot 7\end{array}$ \\
\hline Brown sarson & $\begin{array}{l}\text { Before blooming } \\
\text { Mean }\end{array}$ & $\begin{array}{l}1949-50 \\
1950-1\end{array}$ & $\begin{array}{l}55 \cdot 8 \\
52 \cdot 6 \\
54 \cdot 2\end{array}$ & $\begin{array}{l}140 \cdot 6 \\
\text { I } 8 \cdot 3 \\
124.4\end{array}$ & $\begin{array}{l}202 \cdot 8 \\
195 \cdot 3 \\
199 \cdot 0\end{array}$ & $\begin{array}{l}250 \cdot 7 \\
201 \cdot 4 \\
226 \cdot 0\end{array}$ \\
\hline & $\begin{array}{l}\text { After blooming } \\
\text { Mean }\end{array}$ & $\begin{array}{l}1949^{-}-50 \\
1950^{-1}\end{array}$ & $\begin{array}{l}54 \cdot 8 \\
50 \cdot 4 \\
52 \cdot 6\end{array}$ & $\begin{array}{l}74 \cdot 3 \\
83 \cdot 3 \\
78 \cdot 8\end{array}$ & $\begin{array}{l}179 \cdot 8 \\
153 \cdot 4 \\
166 \cdot 6\end{array}$ & $\begin{array}{l}209 \cdot 5 \\
183 \cdot 8 \\
196 \cdot 6\end{array}$ \\
\hline $\begin{array}{l}\text { Japan sarson: } \\
\text { Light-green leaved }\end{array}$ & $\begin{array}{l}\text { Before blooming } \\
\text { Mean }\end{array}$ & $\begin{array}{l}\text { I } 949^{-50} \\
\text { I } 950-1\end{array}$ & $\begin{array}{l}71 \cdot 3 \\
82 \cdot 8 \\
77 \cdot 0\end{array}$ & $\begin{array}{r}113.9 \\
92.9 \\
103.4\end{array}$ & $\begin{array}{l}206 \cdot 8 \\
174 \cdot 6 \\
190 \cdot 7\end{array}$ & $\begin{array}{l}230 \cdot 5 \\
184 \cdot 4 \\
207 \cdot 4\end{array}$ \\
\hline & $\begin{array}{l}\text { After blooming } \\
\text { Mean }\end{array}$ & $\begin{array}{l}\text { I } 949^{-5}-50 \\
190^{\circ}-1\end{array}$ & $\begin{array}{l}45 \cdot 3 \\
69 \cdot 9 \\
57 \cdot 6\end{array}$ & $\begin{array}{l}64 \cdot 6 \\
86 \cdot 3 \\
75 \cdot 4\end{array}$ & $\begin{array}{l}\text { I } 41 \cdot 9 \\
\text { I } 52 \cdot 4 \\
\text { I } 47 \cdot 1\end{array}$ & $\begin{array}{l}230 \cdot 5 \\
163 \cdot 8 \\
197 \cdot 1\end{array}$ \\
\hline Dark-green leaved & Before blooming & $\begin{array}{l}1949-50 \\
1950-1\end{array}$ & $\begin{array}{l}75 \cdot 7 \\
68 \cdot 9 \\
72 \cdot 3\end{array}$ & $\begin{array}{l}128 \cdot 4 \\
111 \cdot 0 \\
119 \cdot 7\end{array}$ & $\begin{array}{l}\text { I } 82 \cdot 8 \\
\text { I } 89 \cdot 3 \\
\text { I } 86 \cdot 0\end{array}$ & $\begin{array}{l}214 \cdot 3 \\
212 \cdot 2 \\
213 \cdot 2\end{array}$ \\
\hline & $\begin{array}{l}\text { After blooming } \\
\text { Mean }\end{array}$ & $\begin{array}{l}1949^{-}-50 \\
1950^{-1}\end{array}$ & $\begin{array}{l}51 \cdot 4 \\
53 \cdot 2 \\
52 \cdot 3\end{array}$ & $\begin{array}{l}91 \cdot 2 \\
87 \cdot 3 \\
89 \cdot 2\end{array}$ & $\begin{array}{l}155.5 \\
\times 56.6 \\
156.0\end{array}$ & $\begin{array}{l}191 \cdot 9 \\
174.6 \\
183.2\end{array}$ \\
\hline
\end{tabular}

Effect of storage. Loss of ascorbic acid from vegetables during storage is well known to occur, but with the plants under consideration the common practice is to pick them in the evening so that they reach the consumer the following morning; generally, therefore, they are consumed within $24 \mathrm{~h}$ of picking and the risk of deterioration during prolonged storage does not arise. Values for ascorbic acid after $24 \mathrm{~h}$ 
storage are shown in Table 2 , from which it appears that the loss in $24 \mathrm{~h}$ was insignificant.

Effect of cooking. Considerable loss of ascorbic acid is commonly experienced during the cooking of vegetables, whether by boiling in an open vessel or in a pressure cooker, owing to the solubility of ascorbic acid in water. Estimation of ascorbic acid in the brassicas after boiling for $\mathrm{I}$ or for $15 \mathrm{~min}$ showed the expected loss of ascorbic acid, by far the greater part occurring within the ist min. Actual destruction of ascorbic acid was relatively small even in $15 \mathrm{~min}$, since the greater part was still present in the cooking water. It would be desirable to cook the sag in its own water, and it should be possible to do so since all the tissues have a fairly high water content, ranging from $80 \%$ in the buds to $90 \%$ or more in the leaves.

Table 2. Mean concentration of ascorbic acid in fresh tissues of oleiferous brassicas after storage for $24 h$

\begin{tabular}{|c|c|c|c|c|c|c|}
\hline \multirow[b]{2}{*}{ Name of crop } & \multirow[b]{2}{*}{ Stage of sampling } & \multirow[b]{2}{*}{ Year } & \multicolumn{4}{|c|}{ Ascorbic-acid content of: } \\
\hline & & & $\begin{array}{c}\text { Stem } \\
(\mathrm{mg} / \mathrm{IOO} \mathrm{g})\end{array}$ & $\begin{array}{l}\text { Branches } \\
(\mathrm{mg} / \text { toog) }\end{array}$ & $\begin{array}{l}\text { Leaves } \\
(\mathrm{mg} / \mathrm{roog})\end{array}$ & $\begin{array}{c}\text { Buds } \\
(\mathrm{mg} / \mathrm{roO} \mathrm{g})\end{array}$ \\
\hline Toria & $\begin{array}{l}\text { Before blooming } \\
\text { Mean }\end{array}$ & $\begin{array}{l}1949-50 \\
195^{\circ}-1\end{array}$ & $\begin{array}{l}56 \cdot 0 \\
66 \cdot 1 \\
61 \cdot 0\end{array}$ & $\begin{array}{r}118 \cdot 8 \\
95 \cdot 7 \\
107 \cdot 2\end{array}$ & $\begin{array}{l}174 \cdot 7 \\
194.9 \\
189.8\end{array}$ & $\begin{array}{l}199 \cdot 3 \\
208 \cdot 1 \\
203 \cdot 7\end{array}$ \\
\hline & $\begin{array}{l}\text { After blooming } \\
\text { Mean }\end{array}$ & $\begin{array}{l}1949-50 \\
1950-I\end{array}$ & $\begin{array}{l}64 \cdot 0 \\
64 \cdot 9 \\
64 \cdot 5\end{array}$ & $\begin{array}{l}80 \cdot 0 \\
81 \cdot 0 \\
80 \cdot 5\end{array}$ & $\begin{array}{l}121 \cdot 6 \\
171 \cdot 3 \\
146 \cdot 4\end{array}$ & $\begin{array}{l}177 \cdot 1 \\
199 \cdot 4 \\
188 \cdot 7\end{array}$ \\
\hline Brown sarson & $\begin{array}{l}\text { Before blooming } \\
\text { Mean }\end{array}$ & $\begin{array}{l}1949-50 \\
1950-1\end{array}$ & $\begin{array}{l}54 \cdot 3 \\
51 \cdot 5 \\
52 \cdot 9\end{array}$ & $\begin{array}{l}138 \cdot 2 \\
116 \cdot 9 \\
127 \cdot 5\end{array}$ & $\begin{array}{l}183.5 \\
191 \cdot 8 \\
187 \cdot 6\end{array}$ & $\begin{array}{l}243^{\circ} 0 \\
195^{\circ} 9 \\
219^{\circ} 4\end{array}$ \\
\hline & $\begin{array}{l}\text { After blooming } \\
\text { Mean }\end{array}$ & $\begin{array}{l}1949-50 \\
1950-1\end{array}$ & $\begin{array}{l}53 \cdot 4 \\
48 \cdot 0 \\
50 \cdot 7\end{array}$ & $\begin{array}{l}60 \cdot 8 \\
72 \cdot 6 \\
66 \cdot 7\end{array}$ & $\begin{array}{l}176 \cdot 5 \\
148 \cdot 9 \\
162 \cdot 7\end{array}$ & $\begin{array}{l}206 \cdot 1 \\
172 \cdot 6 \\
189 \cdot 3\end{array}$ \\
\hline $\begin{array}{l}\text { Japan sarson: } \\
\text { Light-green leaved }\end{array}$ & $\begin{array}{l}\text { Before blooming } \\
\text { Mean }\end{array}$ & $\begin{array}{l}1949^{-50} \\
195^{\circ}-1\end{array}$ & $\begin{array}{l}64 \cdot 8 \\
75 \cdot 6 \\
70 \cdot 2\end{array}$ & $\begin{array}{r}1 \text { I I } \cdot 5 \\
89 \cdot 8 \\
100 \cdot 6\end{array}$ & $\begin{array}{l}185 \cdot 6 \\
171 \cdot 5 \\
178 \cdot 5\end{array}$ & $\begin{array}{l}216 \cdot 0 \\
181 \cdot 3 \\
198 \cdot 6\end{array}$ \\
\hline & $\begin{array}{l}\text { After blooming } \\
\text { Mean }\end{array}$ & $\begin{array}{l}\text { I949-50 } \\
\text { I950-I }\end{array}$ & $\begin{array}{l}42 \cdot 8 \\
67 \cdot 1 \\
54 \cdot 9\end{array}$ & $\begin{array}{l}62 \cdot 2 \\
76 \cdot 2 \\
69 \cdot 2\end{array}$ & $\begin{array}{l}128 \cdot 4 \\
145 \cdot 1 \\
136 \cdot 7\end{array}$ & $\begin{array}{l}143 \cdot 8 \\
\text { I } 57.6 \\
150.7\end{array}$ \\
\hline Dark-green leaved & $\begin{array}{l}\text { Before blooming } \\
\text { Mean }\end{array}$ & $\begin{array}{l}\text { I949-50 } \\
\text { I950-I }\end{array}$ & $\begin{array}{l}65 \cdot 2 \\
64 \cdot 3 \\
64 \cdot 7\end{array}$ & $\begin{array}{l}125^{\circ} 0 \\
104^{\circ} 7 \\
114^{\circ} 8\end{array}$ & $\begin{array}{l}I 75 \cdot 4 \\
187 \cdot 2 \\
181 \cdot 3\end{array}$ & $\begin{array}{l}206 \cdot 0 \\
192 \cdot 7 \\
199 \cdot 3\end{array}$ \\
\hline & $\begin{array}{l}\text { After blooming } \\
\text { Mean }\end{array}$ & $\begin{array}{l}1949-50 \\
1950-1\end{array}$ & $\begin{array}{l}50 \cdot 7 \\
5 I \cdot 4 \\
5 I \cdot 0\end{array}$ & $\begin{array}{l}88 \cdot 5 \\
78 \cdot 9 \\
83 \cdot 7\end{array}$ & $\begin{array}{l}141.9 \\
149.2 \\
145.5\end{array}$ & $\begin{array}{l}169 \cdot 4 \\
168 \cdot 0 \\
168 \cdot 7\end{array}$ \\
\hline
\end{tabular}

Concentration of ascorbic acid in the seeds and seedlings

The results of the experiments performed with the object of following the concentration of ascorbic acid in the seeds of the plants during ripening and in the seedlings during germination are summarized in Table 3 . As noted by previous workers, a rapid increase in the ascorbic-acid content was observed during germination, the amount in seedlings 3 days old being some six times as great as in the seeds. 
Table 3. Mean concentration of ascorbic acid in fresh tissue of seeds and seedlings of oleiferous brassicas

Name of crop
Toria
Brown sarson
Japan sarson:
Light-green leaved
Dark-green leaved

\begin{tabular}{|c|c|c|c|c|c|}
\hline \multicolumn{6}{|c|}{ Ascorbic-acid content of: } \\
\hline \multicolumn{3}{|c|}{ Seeds } & & & \\
\hline & Fully & & & Seedlings & \\
\hline $\begin{array}{c}\text { Un- } \\
\text { developed } \\
\text { (mg/IOO g) }\end{array}$ & $\begin{array}{l}\text { grown } \\
\text { immature } \\
\text { (mg/roo g) }\end{array}$ & $\begin{array}{c}\text { Mature } \\
\text { (mg/100 g) }\end{array}$ & $\begin{array}{l}\text { I day old } \\
(\mathrm{mg} / 100 \mathrm{~g})\end{array}$ & $\begin{array}{l}2 \text { days old } \\
(\mathrm{mg} / 100 \mathrm{~g})\end{array}$ & $\begin{array}{l}3 \text { days old } \\
(\mathrm{mg} / \text { roo g) }\end{array}$ \\
\hline $302 \cdot 6$ & $27 \cdot 3$ & $12 \cdot 9$ & $63 \cdot 3$ & $129^{\circ} 9$ & $144{ }^{\circ}$ \\
\hline $211 \cdot 3$ & $4 r \cdot 3$ & $15 \% 4$ & $58 \cdot 9$ & $85 \cdot 4$ & $9 \mathrm{I} \cdot 8$ \\
\hline $176 \cdot 2$ & $25 \cdot 3$ & I I 3 & $42 \cdot 6$ & $67 \cdot 2$ & $99 \cdot 2$ \\
\hline 213.6 & $38 \cdot 3$ & I $3 \cdot \overline{6}$ & $63 \cdot 3$ & I I $5 \cdot 9$ & I 14.0 \\
\hline
\end{tabular}

\section{Ascorbic-acid content of other vegetables commonly used in Pakistan}

A survey of the available values (Rasul, 1947) for ascorbic acid in other vegetables commonly eaten in Pakistan suggests that the varieties of brassicas now investigated are outstanding in their ascorbic-acid content. Expressed as $\mathrm{mg} / \mathrm{ro0} \mathrm{g}$ fresh tissue, other common vegetables show a range from about 25 (spinach leaf, inner leaves of cabbage) to 135 (prunings of gram). Except for the stem, the various parts of the oleiferous brassicas may contain up to $200 \mathrm{mg} / \mathrm{ro0} \mathrm{g}$ fresh tissue and should, therefore, serve as a most valuable article of diet.

\section{SUMMARY}

I. The ascorbic-acid content of the stems, branches, leaves and buds of four varieties of oleiferous brassicas recently developed in Pakistan was estimated.

2. The edible portion proved to have an outstandingly high content of ascorbic acid which did not diminish appreciably in the $24 \mathrm{~h}$ after gathering, which is usually the maximum time before the vegetable is eaten.

3. Loss on cooking was not great and was due to diffusion of ascorbic acid into the cooking water.

4. The concentration of ascorbic acid was low in the mature seeds and increased greatly on germination.

Grateful acknowledgement is made to Ch. Zafar Alm, Oilseeds Botanist, Lyallpur, for his helpful suggestions in the course of these studies. My sincerest thanks are also due to Dr H. W. Buston, Imperial College of Science and Technology, London, for assisting with the revision of this article.

\section{REFERENCES}

Harris, L. J. \& Olliver, M. (1942). Biochem. $\mathcal{F} .3^{6}, 155$.

Rasul, G. (1947). Minerals and vitamins in leafy vegetables. M.Sc. Thesis, University of Punjab. 